\title{
The Effect of Macroeconomic Variables on Stock Returns of Companies Listed in the Nairobi Securities Exchange, Kenya
}

\author{
Julia Waruguru Kibara Dr. Fredrick Kalui \\ Department of Accounting and Finance, Egerton University, P.O.Box 536, Egerton
}

\begin{abstract}
This study sought to determine the effect of macroeconomic variables on the stock returns for the companies listed in Nairobi securities exchange. The macroeconomic variables used in this study were money supply, oil prices, gross domestic product and interest rates. The target population for this study was 20 companies Listed in Nairobi securities exchange used in the computation of the NSE 20 share index. This study used secondary data and the data was collected using data collection sheet. The sample data covering a period of 5 years from 2014 - 2018 was collected from various sources.. The descriptive analysis was done using frequencies, percentages, means and standard deviations for all the variables for this study while inferential statistics used in this study were Pearson correlation and both simple and multiple regression analysis. The study found out that Money Supply, Gross Domestic Product, Oil Prices and Interest rates contributed to $71.4 \%$ variation in the stock returns meaning that other factors not included in this study accounted for $28.6 \%$. The study concluded that money supply, oil prices, gross domestic product and interest rate positively affected the stock returns of companies listed in Nairobi Securities Exchange. This study recommends that the macroeconomic environment should be closely monitored in order to ensure stability in the stock market.
\end{abstract}

Keywords: Macroeconomic Variables, Stock Returns, Nairobi Securities Exchange.

DOI: $10.7176 /$ RJFA/12-10-04

Publication date:May $31^{\text {st }} 2021$

\section{Introduction}

A stock market is a facility that helps in the buying and selling of stocks of the public listed companies by the buyers and sellers that gather to trade (Monther \& Kaothar, 2010). The stock prices keep on changing as per market activities influenced by the forces of demand and supply where the prices tend to increase with in the demand of stock and reduce with the increase in the supply of the stocks (Songole, 2012). According to Kalui (2004), stock price volatility is function of many factors not limited to earnings volatility, payout ratio, long term debt, firm size and asset growth. Stock market attracts so many investors through the availability of various opportunities that give them returns. Nairobi securities exchange is a very important institution to the growth of the Kenyan economy as it helps in the creation of wealth and helps the investors with an avenue for investing their resources (Junkin, 2012). In addition, private companies and the government are also beneficiaries of stock market in acquiring funds to support their projects and to meet their daily operational costs (Ndegwa, 2015).

Nairobi securities exchange act as an intermediary between the investors and borrowers and this facilitates the circulation of money in the economy. Listed companies in the Nairobi securities exchange benefit from stock market through the ability to be able acquire long term capital through public initial offer and hence they are able to expand their business activities and meet their daily operational costs. Brealey, Myers, and Allen (2011) suggested that a market has efficiency when it is impossible for an investor to make extreme returns. It therefore means that the returns earned would be equal to the market return. The fair value of shares is then a reflection of the worth of a company and of which is usually represented by the anticipated future cash flows discounted at a cost of capital.

Stock return is a profit or loss that an investor gets from investing in stock and it constitutes of any change in value of the investment and cash flows which investor receives from the investment in that stock. Stock return maybe measured in absolute terms for instance dollars or as a percentage of the amount invested. In other words, stock return is a combination of dividends and increases in the stock price that is known as capital gain.

So many stocks of listed company are traded on daily basis in a Securities exchange market. For investors to evaluate the performance of a stock market, they observe and analyze the level of the various aggregate market indices before making a decision of investing their wealth. A market index is an aggregate value that is arrived at by combining several stocks together and expressing their total values against a base value and this is usually from a specific date. Historical stock market performance and benchmark for comparison against performance of individual investor portfolios are provided by the market indices. Investors use market indices to forecast the trends of market performance in future (Zhang, 2009).

Ariemba Kiweu and Riro (2015) noted that the Kenya National Bureau of Statistics normally provides data on various economic development indicators, like inflation, informal sector employment, national savings rate, gross domestic product, growth rate, gross domestic product per capita among others. The World Bank (2012) states that world development indicators report, noted that a macroeconomic element is one that is relevant to a 
wide-ranging economy at the county or nationwide level and touches a great resident of a country. Examples of such influences comprise of inflation, unemployment, gross domestic product among others.

\section{Statement of the Problem}

The NSE 20 share index has been fluctuating over time and hence affecting the stock returns of the quoted companies at the Nairobi securities exchange (Kamande, 2015).Volatility in stock returns is one of the leading problems facing Nairobi Securities Exchange as noted in the sessional paper No. 10 of 2012 on Kenya Vision 2030. Stock returns volatility has an effect of eroding investors' confidence in making investment decisions in the Nairobi Securities Exchange. Stock return volatility has been linked to macroeconomic variables where some of the theories in finance such Arbitrage Pricing Theory have viewed macroeconomic variables as predictors of stock returns volatility.

Studies have been done on effect of macroeconomic variables on stock returns but have shown conflicting results .Hence there is no consensus on the effect of macroeconomic variables on stock returns. For instance, Ouma and Muriu (2014) and Kirui (2014) using OLS found insignificant effect of interest rate on stock return while Gatebi (2013), Olweny, and Omondi (2014) found a negative effect. Olweny and Omondi (2014), Ouma and Muriu (2014) confirmed inflation to be significant while Kirui (2014) found it to be insignificant. This study will seek to fill the above gaps by using different macroeconomic variables to give valid results.

\section{Objectives of the study}

The general objective of this study is to determine the effect of selected macroeconomic variables on stock returns of companies listed in NSE.

\section{Research Hypotheses.}

Ho: There is no significant effect of money supply, oil prices, gross domestic product and interest rate on stock returns of the companies listed in the Nairobi Securities Exchange.

\section{Justification of the Study}

The findings of this study will help firms' managers, government and interested parties to formulate a sustainable model that will help in running the companies and hence generating a lot of income in the end. These plans will also help in smooth running of firms' affairs and managers will have easy time in running the firms. This study will be of great help to the Central Bank of Kenya (CBK), Capital Markets Authority and Kenya Revenue Authority (KRA) since it will help them to improve their control systems and hence improve their services to the public and will use the study findings to improve on the framework for regulation.

This study will also be useful to the management and staffs of firms by helping them to put in place structures that will enable in improving performance of their stocks hence enabling their firms to be profitable. Academicians who engage in financial research will find it useful as one of the working documents. They will be able to answer the question whether or not CMA should intervene in stock prices management of the listed firms.

\section{Literature Review \\ Stock Returns}

Mugambi and Okech (2016) defined stock returns as the increase or decrease in the value of a stock and it is usually given as a percentage and the stock returns comprise of any capital gains and any revenue that is received from the investment in the financial asset. Capital gain is calculated from the difference of price of a stock within two given period and then that difference is divided by the price at the beginning of the period. Investors in the stock market look at stock return as a motivating factor that they consider before investing in a stock.

Stock returns depends on the availability of enough flow of information in the market and how effective and efficient the stock returns are allocated. Volatility of stock prices that causes uncertainty in stock returns usually influences the demand and supply of the stocks (Taofik \& Omosolo, 2013). Aliyu (2011) high stocks returns are associated with high profits and hence the firm is said to greatly contribute to the growth and development of the economy of a country and in turns this is likely to attract so many investors to come and invest in that firm's stocks. This makes the issue on stocks' volatility to attract the attention of researchers in the whole economy as deterioration in the economic growth trends creates an environment that is difficult for consumption and investment (Erdugan, 2012).

Stock returns can is said to be the attached value a financial asset that it can earn from the market which depends on the company's performance. Stocks returns can also be defined as the present value of the expected earnings in the future and which is discounted by a constant rate of return. From this definition, it can be concluded that the stock returns are determined by the amount of income that a firm receives which is the future cash flows and the expected returns. Sifunjo and Mwasaru (2012) stock return volatility at the Nairobi securities exchange are determined by interactions between borrowers and savers of the funds and which directly influences market 
capitalization of the individual firms and in the entire market as a whole.

Stock markets are mostly measured using stock market indexing. NSE 20 share index is used in the calculation of stock returns as it acts as a benchmark for the measurement of the performance of the stock market. This study will use NSE 20 Share index as variable of measure for stock returns. The dividends will be ignored since it is not possible for dividends to be paid quarterly. Monthly NSE 20 Share index data will be obtained from the NSE website.

\section{Macroeconomic variables}

Macroeconomic variables are those economic fundamentals that have the potential of affecting the performance of the country's economy, the stock market returns and stock price volatility (Kitati, Zablon, \& Maithya, 2015). Examples include employment/unemployment rate, foreign exchange rates, gross domestic product, money supply, interest rate, industrial production rate, inflation rate. Macroeconomic variables are variables that control the macro-economy, that is, the whole economy (Olukayode \& Akinwande, 2009). Macroeconomic factors influence the existence, behavior and performance of companies. The impact of these factors may be direct such as competitors or indirect such as business climate. Atanda (2012) Gross Domestic Product, unemployment, exchange rate and inflation were identified as the variables that have a major influence on the economy. This study used crude oil prices, money supply, gross domestic product and interest rate. The choice of this macroeconomic variables was based on the empirical review where there is no such combination used.

\section{Crude oil}

Crude oil is a very important factor for the production process and hence the price of the oil is important input in the production process. This makes the oil price to be used as the measure for the real economic activity in a country. A rise in oil price in the international market would mean lower economic activity in every sector of a country and this has an effect of decreasing the stock returns (Kuwornu, 2011). Surplus oil production would lead to lowering of the oil prices in the international market and this will lead to increase in real economic activity that in turn would lead to increase in stock prices. Subsequently Increase in stock prices lead to increase in oil prices (Basher \& Sadorsky, 2011). Future cash flows are determined by the stock prices that are directly influenced by the oil prices. Oil prices can indirectly affect the stock prices through influencing the interest rate that is essential in discounting the future cash flow. There is profit reduction when there is lack of adequate balancing of the influence between essentials of production, increase in the oil prices, for instance increase in cost of performing business activities and for companies not relate to oil production. There is effect of inflating the prices of the final products and hence a negative effect to the consumers, this will eventually reduce the profits and hence the stock prices since the demands of final goods and services will fall (Basher \& Sadorsky, 2011). Central banks and policy makers responds to general increase in consumer goods in a country by increasing interest rates which then it discount rate used in discounting the future cash flows.

\section{Inflation}

Basu (2011) defined inflation as a general rise in prices of goods and services across the board. The most common indicators used to measure inflation are consumer price index and producer price index. PPI tracks the average price of a basket of goods that a company uses to transform them into finished products. Barnor (2014) stated that inflation rates could have either positive or negative repercussions. Higher producer inflation depletes company profits, shrink's expansion, and the growth of markets and consequently increases unemployment because companies cease to hire workers. Stock prices rise or fall based on production indices signals. Inflation is defined as existence of general rise in the prices of consumable goods and services for a prolonged period. Inflation is caused by increase in disposable income and reduction in production of essential goods and services. Inflation has an effect of reducing buying power of the low-income earners and hence they are usually not able to acquire essential goods and services.

\section{Foreign exchange rate}

Foreign Exchange rate is the rate at which domestic currency can be exchanged for another country's currency. According to Schiller (2008), exchange rates can be expressed as either a direct or indirect quotation Foreign exchange rate evaluates the currency of one country to another. It defines how much of local currency is required to procure the same basket of commodities and services as in another country as it would in the local country. Exchange rate influences the comparative value between local and international goods and the foreign appetite for local goods (Ncube \& Ndou, 2011).

Nominal exchanges rates can be have been used by many studies to value the changes in the international exchange rates although it can also be valued in real terms. Increase in the value of the local prices decreases the demands of a country's products since other country will have to pay more and hence the stocks of the firms in that country will reduce since investors will not be willing to invest in such companies, this is as explained by 
good market theory. Due to low demand of country's firms by the investors, the markets returns of an economy that rely on other countries will likely fall. There is a notion that stock returns and exchange rates are inversely related and hence increase in exchange rates will lead to decrease in stock returns while decrease in the exchange rates will lead to increase in stock returns. The relationship between the stock markets and the exchange rate market as explained by the portfolio balance theory although the level of the relationship of the empirical studies is still not clear and sometimes the results are contradicting.

\section{Gross Domestic Product}

Gross domestic product is the total production of a country in a specific period valued in monetary terms (Schiller, 2008). Gross domestic product per capita is a good measure for economic recession and the recovery thereafter. Gross domestic product is a measure of aggregate income earned by a country from its local and foreign elements of production. A momentous change in gross domestic product either positive or negative impacts directly on the stock market return. An economic outlook that promises an expansion of the economy will certainly cause stock prices to rise because a rational investor will seek to buy stocks and benefit from the proceeds of an expanded economy. The opposite is also true when it is anticipated that there is going to be a recession of the economy, stock prices tend to decline with investors opting to sell their stock and purchase securities with a lesser risk such as bonds. Wang (2013) states that gross domestic product is usually the preferred macroeconomic factor to arrive the overall economic productivity within an economy; the rate of growth of the gross domestic product reflects the state of the economic phases.

\section{Interest Rate}

Interest rate is the cost of borrowing money. Interest rate is the part of loan that an investor will ask because of using his money. Interest rate refers to the cost expressed as a percentage of the principal charged by the lender to the borrower for lending the money. This Study will use Central Bank of Kenya Lending Rate as a proxy to measure interest rate. Songole (2012) noted that investors substitute buying stocks of optimal interest rates are resulted by the interaction of market mechanism of money in an economy (Darfor \& Agyapong, 2010). The government through central bank usually adjusts the interest rates as necessary so as to control amount of money in circulation. Many of the studies conducted on the relationship between macroeconomic variables and stock returns found that interest rates negatively significantly affect the stock returns. Olweny (2011) found the interest rates were significant in affecting stock returns for firms listed in Nairobi Stock Exchange. Central Bank of Kenya Lending Rate will be used as an indicator for interest rates for this study.

\section{Unemployment Rate}

The unemployment rate is another significant indicator used to measure the underutilization of labor supply in a country. It is outlined as one of the most fundamental significant indicator in the economy and a key measure in the labor market. Unemployment rate is the proportion of the people with ability and willingness to work at the prevailing wage rate but they cannot secure job opportunities. Unemployment rate is expressed as a percentage of the total work force. Information on unemployment signals market participants on the strength and wealth of the economy. It becomes very difficult to find job opportunities when unemployment rate level is high and also the wage rate is very low as the salary increases and promotions are minimal.

Low employment rate shows a good economic performance hence the government will always work hard to minimize unemployment rate. A higher employment rate means higher economic output, more sales, higher returns and high corporate profits. Stock prices and stock market returns rise or fall with increase or decrease in the employment rate. Unemployment rate announcement by ILO is one of the information that flows in the stock market in the stock market and has a significant effect to the stock prices and hence stock returns (Mwaore, 2017). High unemployment rate means slow growth, low corporate profits, falling stock prices and low stock market return.

The balance of payments is the difference between the total amount of goods a country exports and the total amount of goods a country imports. If the amount of goods that a country exports is greater than the amount of goods that a country imports, there is a balance of payments deficit.

\section{Economic Growth}

Economic growth is the amount that the level of output within an economy increases over a given time period (again usually measured over a year). Economic growth is extremely desirable as it means that, in general, the people within an economy are getting richer. Economic growth can be increased in a number of ways, such as technological improvement, an increased in the demand for goods and services, and an increase in the size of the workforce (a fall in unemployment). 


\section{Money Supply}

Money Supply is the total quantity of money in the economy at any given time. It is measured as average yearly monetary base (M3); the sum of currency in circulation, and reserve balances. Money is a collection of liquid assets that is generally accepted as a medium of exchange and for repayment of debt. In that role, it serves to economize on the use of scarce resources devoted to exchange, expands resources for production, facilitates trade, promotes specialization, and contributes to a society's welfare. This study will use M2 as a proxy for measuring the money supply. The money supply data is collected, recorded and published periodically, typically by the country's government or central bank.

\section{Nairobi Securities Exchange (NSE)}

The Nairobi securities exchange was established in 1954 as Nairobi stock exchange by a group of voluntary stockbrokers who were registered under the Societies Act in British Kenya. Nairobi securities exchange is located in Nairobi that is the capital city of Kenya. Its chairperson is Samuel Kimani and its CEO is Geoffrey Odundo. Nairobi security exchange deals with Kenya Shillings Currency. Currently it has listed sixty-four companies distributed in different segments. It is a member of Africa Securities Exchange Association. The listed companies are in different industry such as investment, insurance, and construction, automobile, commercial and services, agriculture, and banking.

Nairobi securities exchange is a market that is used by the listed companies and the Government uses to exchange their financial securities. Capital Market Authority (CMA) is the institution that is responsible for overseeing the activities of Nairobi Securities Exchange. Capital Market Authority (CMA) has the responsibility of giving a trading platform for securities of the listed companies at the Nairobi Securities Exchange. The total number of companies listed at Nairobi Securities Exchange as at 2018 was 65. Nairobi Securities Exchange facilitates conversion of the savings to investment in profitable avenues rather than keeping it unutilized. This encourages both local and foreign investors to have a habit of investing since they are assured of some returns.

Many policies have been formulated and implemented to facilitate growth and advancement of the Nairobi Securities Exchange hence giving confidence and morale to both individual and private investors to save and invest their funds in the stock market. Giving Capital Market authority to regulate the functioning of the Nairobi Securities Exchange and eradication of differences between leverage and shares in order to have a variety in the stock market is some of the policies that have been developed (Kemboi \& Tarus, 2012). Regulations to guide the giving out of the commercial papers and corporate bonds and also significant outline on the changes that listed firms corporate governance systems that are intended to give investors assurance were issued by the Capital Market Authority (Kemboi \& Tarus, 2012).

NSE 20 share index is one of the commonly index used in Nairobi securities exchange for measuring the returns of the 20 best performing companies listed in the Nairobi securities exchange. Index is a combination of various stocks that is a representative of the whole market. The index is used by the investors to monitor the performance of a stock market and hence they are able to make investment decisions (NSE, 2016). Nse 20 share index is which is arrived at by finding the average of shares of the 20 best performing companies listed at the Nairobi Securities Exchange. The companies are reviewed by NSE from time to time usually at the end of the day. Where some of the companies are dropped and some added to the list. For a company to be included in the list of the 20 companies used in the calculation of the Nse 20 share index it must have at least $40 \%$ market capitalization, its shares that are traded in the Nse must at minimum be $20 \%$, liquidity of $20 \%$ and must have a turnover of at least $10 \%$;A free float of at least $20 \%$ is also a requirement; At least a market capitalization of Kshs. 20 million and also the company should have a good record of high profit and dividend.

\section{Conceptual framework}

Conceptual framework is a graphical or diagrammatic representation the relationship between variables in a study it helps the researchers and it helps the researchers see the proposed relationship easily and quickly. 


\section{Independent Variables}

Macroeconomic variables

\section{Dependent Variable}

Stock Returns

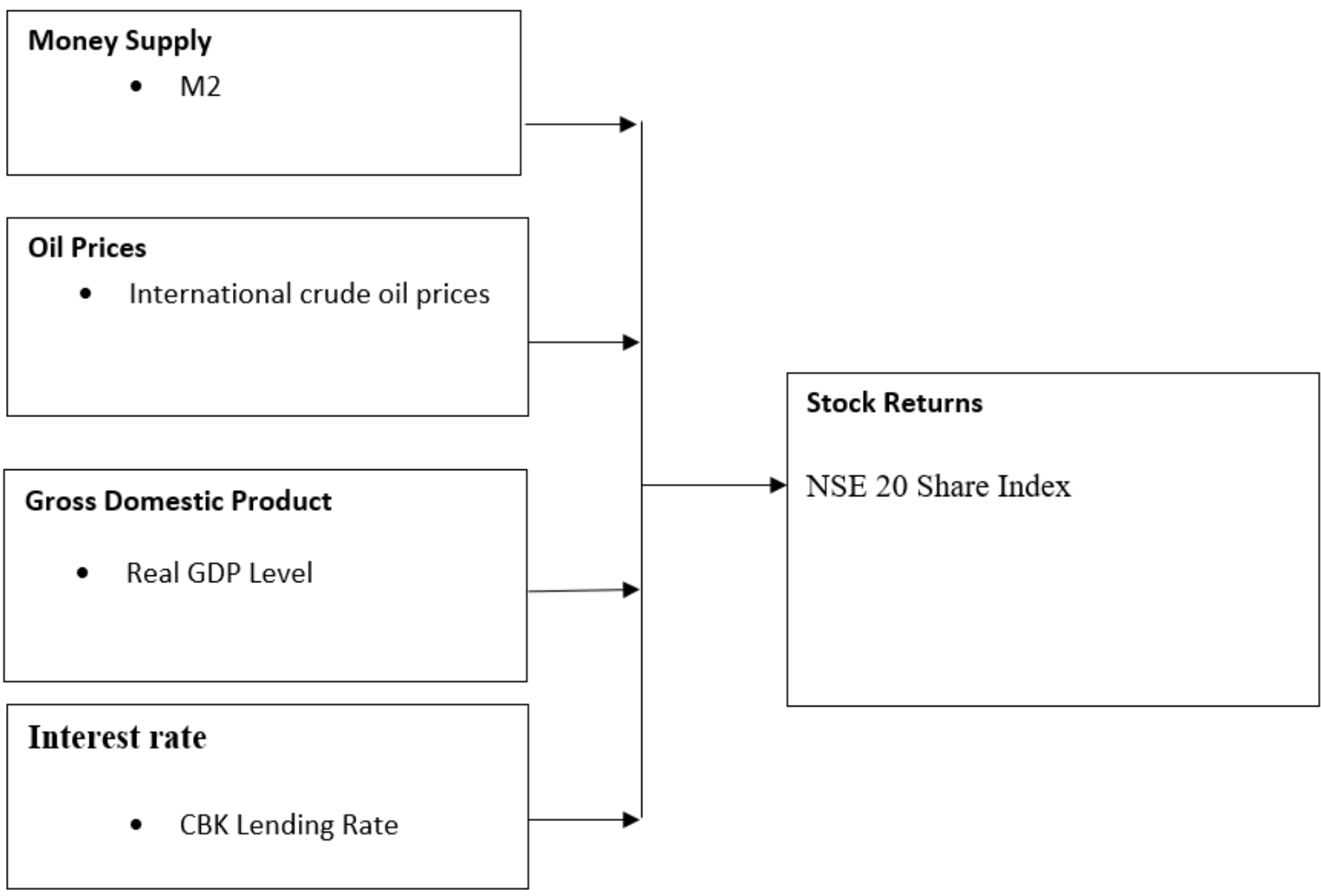

\section{Research Methodology and Results}

This study adopted descriptive research design. Descriptive design is a design that quantitatively describes relationship between or among the variables. Descriptive research design was suitable for this study since it helped in achieving the main objective of this study and which involved description of macroeconomic variables and stock returns and the data obtained was for a given period. The target population for this study was 20 companies used in the computation of Nse 20 Share Index. The 20 firms acted as a representative the population. A census approach was used in this study since the number of the firms is small. The choice of the 20 firms in this study is because these are the best performing firms in the market and they are they are selected from all the sectors in the Nairobi Securities Exchange and hence it is the best for this study.

This study used secondary data for the purpose of analysis. Quarterly data for a period of 5years (January 2014 to December 2018) was collected. The data for Nse 20 share index will be extracted from the Nairobi Securities Exchange handbooks for the period 2014-2018 and was used as a proxy for measuring stock returns. This will be done by use of desk search techniques and by visiting the NSE. The data for interest rate and money supply was obtained from CBK while data for oil prices and GDP was obtained from KNBS. Both descriptive and inferential analysis was done. Descriptive analysis involved frequencies and percentages, means and standard deviations across all variables (independent and dependent variables

Pearson correlation coefficient was used to determine the strength and direction of independent variables on dependent variable while multiple regression model was used to test the hypothesis. The study used 0.0 .5 significance level to make the decision on whether to accept or reject the null hypothesis. The F-statistics at $95 \%$ confidence level was used to determined significance relationship between the dependent variable and independent variables. The following multiple regression model was adopted.

$\mathbf{Y}=\boldsymbol{\beta}_{\mathbf{0}}+\boldsymbol{\beta}_{1} \mathbf{X}_{\mathbf{1}}+\boldsymbol{\beta}_{\mathbf{2}} \mathbf{X}_{\mathbf{2}}+\boldsymbol{\beta}_{\mathbf{3}} \mathbf{X}_{\mathbf{3}}+\boldsymbol{\beta}_{\mathbf{4}} \mathbf{X}_{\mathbf{4}}+\boldsymbol{\varepsilon}$. Where:

$\mathrm{Y}=$ the parameters Stock returns, $\mathrm{B}_{0}=$ Constant, $\mathrm{X}_{1}=$ Money Supply, $\mathrm{X}_{2}=$ Oil Prices, $\mathrm{X}_{3}=$ Gross Domestic Product, $\mathrm{X}_{4}$ $=$ Interest Rate, $\boldsymbol{\varepsilon}=$ Error Term, $\beta_{1}, \beta 2, \beta_{3}$ and $\beta_{4}$ represent Regression coefficients of Independent variables. 


\section{Descriptive Statistics}

Stock Returns

Table 1: Stock Returns

\begin{tabular}{lllll}
\hline Year & Mean & SD & Skewness & Kurtosis \\
\hline 2014 & 5043.6850 & 181.3895 & 0.0301 & -1.1887 \\
2015 & 4592.1250 & 579.7091 & 0.2474 & -4.1122 \\
2016 & 3513.0300 & 372.3386 & 0.6551 & -2.1608 \\
2017 & 3545.7750 & 295.1822 & -1.7575 & 3.0969 \\
2018 & 3711.5000 & 81.9939 & -1.0646 & 1.3635 \\
\hline Average & $\mathbf{4 0 8 1 . 2 2 3 0}$ & $\mathbf{3 0 2 . 1 2 2 7}$ & $\mathbf{- 0 . 3 7 7 9}$ & $\mathbf{- 0 . 6 0 0 3}$ \\
\hline
\end{tabular}

The study measured the stock returns using the NSE 20 share index, the average mean of 20 share index recorded was 4081.2230, the average standard deviation was 302.1227 and the average skewness was -0.3779 and the kurtosis value was -0.6003 . the findings depicts that the average mean was above 2,500 points which means the performance of the firm was adequate thus the stock return was good as depicted by 20 share index. The index reflects the simple arithmetic average of the prices relative of sample stocks on certain date in relation to the base date the equal weighted index assumes that the investor invests an equal amount of money in each stock included in the index. An example of such an index is the NSE 20 share index. The value-weighted index reflects the aggregate market capitalization of sample stocks of certain date in relation to the base date. The study recorded a decrease of the stock returns measured by NSE 20 share index from the year 2014 at 3.702 to a value of 3.54 in the year 2016 and also picked an increase value to the last year. This implies the 20 -share index performance was not constant because of political issues over that duration.

\section{Money Supply}

Table 2: Money Supply.

\begin{tabular}{lllll}
\hline Year & Mean & SD & Skewness & Kurtosis \\
\hline 2014 & 1882333.0000 & 93231.2977 & 0.1952 & -0.1966 \\
2015 & 2161467.2500 & 90180.7314 & 0.5723 & 1.6758 \\
2016 & 2357946.7500 & 33243.3998 & -1.8438 & 3.4635 \\
2017 & 2500160.0000 & 54910.2154 & -1.0045 & 0.5412 \\
2018 & 2670927.5000 & 80924.1593 & -0.8950 & 1.9456 \\
\hline Average & $\mathbf{1 7 6 2 1 3 0 . 8 0 0 0}$ & $\mathbf{6 8 3 2 7 . 8 8 2 4}$ & $\mathbf{- 0 . 4 3 6 6}$ & $\mathbf{0 . 1 3 7 4}$ \\
\hline
\end{tabular}

The money supply average mean was 1762130 with the highest mean recorded on 2018 at 2670927.5 and the lowest mean recorded at 1882333 at 2014 . The standard deviation was 68327.8824 and the skewness and kurtosis was -0.4366 and 0.1374 respectively. Overall, an increase in the supply in an economy leads to lower interest rates and higher consumer spending because the disposable income of consumers is higher. For instance, when the FED reduces the interest rate, banks can borrow money cheaper than before and can issue loans to consumers less expensively than before. Thus, more consumers take out loans and purchase houses and other goods. Since consumers spend more, firms increase their output to meet consumer needs and consequently, their profits. At the same time, employment rises as more workers are hired due to the increase in production. On the other hand, an increase in the money supply often leads to higher inflation because as consumers spend more, the general level price rises. The study recorded a constant increase in the money supply from the year 2014 at 6.27 to a value of 6.426 in the year 2018. This implies there was a constant release of the money by the government to the economy in order to cushion the inflation rates.

\section{Oil Prices}

Table 3: Oil Prices in Kenya Shillings

\begin{tabular}{lllll}
\hline Year & Mean & SD & Skewness & Kurtosis \\
\hline 2014 & 14098.06 & 973.6304 & -0.803615 & -0.88091 \\
2015 & 12412.95 & 422.7802 & 0.24561311 & -3.3565 \\
2016 & 12318.83 & 716.6355 & -0.1128889 & -2.44757 \\
2017 & 13895.15 & 376.0447 & 1.5459927 & 2.118308 \\
2018 & 15463.03 & 844.6612 & 0.77688955 & 0.404066 \\
\hline Average & $\mathbf{1 3 6 3 7 . 6}$ & $\mathbf{6 6 6 . 7 5 0 4}$ & $\mathbf{0 . 3 3 0 3 9 8 2 9}$ & $\mathbf{- 0 . 8 3 2 5 2}$ \\
\hline
\end{tabular}

The study registered an average mean of 13637.6 Kenya shillings, the standard deviation was 666.7504 while the skewness was 0.3303 and the kurtosis was -0.8352 , the findings depicts that oil prices influence the stock returns but to a small magnitude, the study also found out the skewness was normally distributed. The study registered a decrease in the oil prices from the value of 4.14 in the year 2014 to a value of 4.09 and now registered an increase in the prices to value of 4.189 in the year 2018. This was a result of fluctuation in the exchange rates 
more specifically the US dollar.

Gross Domestic Product

Table 4: Gross Domestic Product

\begin{tabular}{lllll}
\hline Year & Mean & SD & Skewness & Kurtosis \\
\hline 2014 & $125,027.67$ & 1909.432 & 0.00016341 & -1.19922 \\
2015 & $141,785.45$ & 21187.93 & 1.70026778 & 3.195116 \\
2016 & $130,172.75$ & 17216.14 & 1.85074074 & 3.435193 \\
2017 & $318,639.59$ & 24771.32 & -0.666485 & 0.121867 \\
2018 & $395,807.05$ & 28429.16 & 0.25899731 & -1.56117 \\
\hline Average & $\mathbf{2 2 2 , 2 8 6 . 5 0}$ & $\mathbf{1 8 , 7 0 2 . 8 0}$ & $\mathbf{0 . 6 3}$ & $\mathbf{0 . 8 0}$ \\
\hline
\end{tabular}

Gross domestic product is the total value of everything produced in the country. It does not matter if it is produced by citizens or foreigners. If they are located within the country's boundaries, their production is included in GDP. GDP affects personal finance, investments, and job growth. Investors look at a nations' growth rate to decide if they should adjust their asset allocation. They also compare country growth rates to find their best international opportunities. The average mean of the study was 222,286.50, the standard deviation was $18,702.80$, the skewness, and kurtosis was 0.63 and 0.80 respectively.

The study recorded a fluctuating gross domestic product where there was an increase in 2014 to 2015 and a reduction for 1 year and a constant increase in the performance from the year 2016 to the year 2018 at a value of 5.59 .

Interest rate

Table 5: Interest rate

\begin{tabular}{lllll}
\hline Year & Mean & SD & Skewness & Kurtosis \\
\hline 2014 & 16.325 & 0.423045 & 1.22835734 & 0.686218 \\
2015 & 16.66 & 1.226812 & 0.89218499 & 0.387952 \\
2016 & 15.8925 & 2.467001 & 0.00796791 & -5.88859 \\
2017 & 13.65 & 0.033665 & $-1.494 \mathrm{E}-13$ & -0.1609 \\
2018 & 12.97 & 0.462097 & 0.19664945 & -3.92089 \\
\hline Average & $\mathbf{1 5 . 0 9 9 5}$ & $\mathbf{0 . 9 2 2 5 2 4}$ & $\mathbf{0 . 4 6 5 0 3 1 9 4}$ & $\mathbf{- 1 . 7 7 9 2 4}$ \\
\hline
\end{tabular}

The interest rate is the amount a lender charges for the use of assets expressed as a percentage of the principal. The interest rate is typically noted on an annual basis known as the annual percentage rate (APR). The assets borrowed could include cash, consumer goods, or large assets such as a vehicle or building. When the borrower is seen as a risk averse by the lender, the borrower will usually be charged a lower interest rate. If the borrower is considered high risk, the interest rate that they are charged will be higher. The average mean of 15.0095 was recorded; the mean of 16.325 , the 0.9225 , the skewness and kurtosis was 0.4650 and -1.7792 .

High interest rates make loans more expensive. When interest rates are high, fewer people and businesses can afford to borrow. That lowers the amount of credit available to fund purchases, slowing consumer demand. At the same time, it encourages more people to save because they receive more on their savings rate. High-interest rates also reduce the capital available to expand businesses, strangling supply. This reduction in liquidity slows the economy. Low interest rates have the opposite effect on the economy. Low mortgage rates have the same effect as lower housing prices, stimulating demand for real estate. Savings rates fall. When savers find they get less interest on their deposits, they might decide to spend more. The interest income was fluctuating where there was an increase in 2014 at 1.21 to a value of 16.66 and recorded a constant decrease in the performance of the interest income to a value of 1.11 in the year 2018 . 
Inferential Statistics

Correlation Analysis

Table 6: Correlation Coefficient Matrix of stock returns and macro-economic factors

\begin{tabular}{|c|c|c|c|c|c|c|}
\hline & & $\begin{array}{l}\text { Stock } \\
\text { Returns }\end{array}$ & $\begin{array}{l}\text { Money } \\
\text { Supply }\end{array}$ & $\begin{array}{l}\text { Oil } \\
\text { Prices }\end{array}$ & $\begin{array}{l}\text { Gross } \\
\text { Domestic } \\
\text { Product } \\
\end{array}$ & $\begin{array}{l}\text { Interest } \\
\text { Rate }\end{array}$ \\
\hline Stock & Pearson Correlation & 1 & $.697^{*}$ & .518 & $.847^{* *}$ & $.813^{* *}$ \\
\hline \multirow[t]{2}{*}{ Returns } & Sig. (2-tailed) & & .037 & .153 & .004 & .008 \\
\hline & $\mathrm{N}$ & 5 & 5 & 5 & 5 & 5 \\
\hline Money & Pearson Correlation & $.697^{*}$ & 1 & .378 & .523 & .491 \\
\hline \multirow[t]{2}{*}{ Supply } & Sig. (2-tailed) & .037 & & .315 & .149 & .179 \\
\hline & $\mathrm{N}$ & 5 & 5 & 5 & 5 & 5 \\
\hline Oil & Pearson Correlation & .518 & -.378 & 1 & .306 & -.439 \\
\hline \multirow{2}{*}{ Prices } & Sig. (2-tailed) & .153 & .315 & & .424 & .237 \\
\hline & $\mathrm{N}$ & 5 & 5 & 5 & 5 & 5 \\
\hline Gross & Pearson Correlation & $.747^{* *}$ & .523 & .306 & 1 & $.746^{* *}$ \\
\hline Domestic & Sig. (2-tailed) & .004 & .149 & .424 & & .004 \\
\hline Product & $\mathrm{N}$ & 5 & 5 & 5 & 5 & 5 \\
\hline Interest & Pearson Correlation & $.713^{* *}$ & .491 & .439 & $.746^{* *}$ & 1 \\
\hline \multirow[t]{2}{*}{ Rate } & Sig. (2-tailed) & .008 & .179 & .237 & .004 & \\
\hline & $\mathrm{N}$ & 5 & 5 & 5 & 5 & 5 \\
\hline \multicolumn{7}{|c|}{$\begin{array}{l}\text { *. Correlation is significant at the } 0.05 \text { level (2-tailed). } \\
\text { **. Correlation is significant at the } 0.01 \text { level (2-tailed). }\end{array}$} \\
\hline
\end{tabular}

\section{Regression analysis}

Joint effect of money supply, oil prices, gross domestic product and interest rates on stock returns of the companies listed in the Nairobi Securities Exchange.

Table 7: Model summary for combined influence

\begin{tabular}{|l|l|l|l|l|}
\hline Model & R & R Square & Adjusted R Square & Std. Error of the Estimate \\
\hline 1 & $.924^{\mathrm{a}}$ & .854 & .708 & .59060 \\
\hline
\end{tabular}

a. Predictors: (Constant), Money Supply, Oil Prices, Gross Domestic Product and Interest Rate.

Table 8: ANOVA for combined influence

\begin{tabular}{|ll|l|l|l|l|l|}
\hline Model & & Sum of Squares & Df & Mean Square & F & Sig. \\
\hline \multirow{4}{*}{1} & Regression & 8.160 & 4 & 2.040 & 5.849 & $.048^{\mathrm{b}}$ \\
& Residual & 1.395 & 4 & .349 & & \\
& Total & 9.556 & 8 & & & \\
\hline
\end{tabular}

a. Dependent Variable: Stock Returns

b. Predictors: (Constant), Money Supply, Oil Prices, Gross Domestic Product, Interest Rates.

Table 9: Regression Coefficients for combined influence

\begin{tabular}{|l|l|l|l|l|l|}
\hline \multirow{2}{*}{ Model } & Unstandardized Coefficients & Standardized Coefficients & T & Sig. \\
\cline { 2 - 5 } & $\mathrm{B}$ & Std. Error & Beta & & \\
\hline (Constant) & .646 & .385 & & .333 & .253 \\
Money Supply & .274 & .225 & .283 & .216 & .021 \\
Oil Prices & .166 & .202 & .183 & .826 & .045 \\
Gross Domestic Product & .312 & .236 & .496 & .321 & .025 \\
Interest Rate & .127 & .279 & .174 & .454 & .046 \\
& & & & & \\
\hline
\end{tabular}


Dependent Variable: Stock Returns

The study sought to determine the effect of money supply, oil prices, gross domestic product and interest rates on stock returns of the companies listed in the Nairobi Securities Exchange .Multiple regression was used in this study to test the fifth hypotheses which is states that there is no significant joint effect of money supply, oil prices gross domestic product and interest rates on stock returns of the companies listed in the Nairobi Securities Exchange.

The ANOVA (Analysis of Variance) results on table above shows that the F value 5.849 was statistically significant at 0.08 , which was lower than 0.05 . The model was a good fit for the data since the F statistics of 5.849 is greater than $\mathrm{F}$ critical of 3.44 that is, $(5.849>3.44)$ and $\mathrm{P}$ value of 0.08 which is less than 0.05 . Since the model was a good fit, it was therefore used for determination of the effect of interest rates on stock returns for the companies listed in the Nairobi Securities Exchange. The above results also show that the independent variables (interest rates) used was statistically significant in predicting the stock returns at $95 \%$ significance level.

As per the SPSS generated table 4.23, the established regression equation was:

$\mathrm{Y}=0.646+0.274 \mathrm{X}_{1}+0.166 \mathrm{X}_{2}+0.312 \mathrm{X}_{3}+0.127 \mathrm{X}_{4}$

Holding Money supply, Oil Prices, Gross Domestic Product and Interest rates constant the stock returns would be 0.646 . Independent variables from the regression equation reveal that a unit increase in money supply led to an increase in stock returns by 0.274 units. A unit increase in oil prices led to an increase in stock returns by 0.166 units. In addition, a unit increases in interest rates led to an increase of stock returns by 0.127 units, also a unit increase in GDP led to an increase in stock returns by 0.312 units.

The ANOVA results depict that there is a statistical significant relationship between money supply and stock returns of the companies listed in the Nairobi Securities Exchange, and this is indicated by $\mathrm{P}-$ value $=0.048<$ 0.05.The null hypothesis (H05) which states that there is no significant joint effect of money supply, oil prices, gross domestic product and interest rates on stock returns of the companies listed in the Nairobi Securities Exchange was rejected because the $\mathrm{P}$ value $=0.048$ is lower than 0.05 .

\section{Conclusion}

The study sought to determine the effect of money supply, oil prices, gross domestic product and interest rate on stock returns of companies listed in the Nairobi securities exchange. Based on the findings of the study, the selected macroeconomic variables had a significant joint effect on the stock returns of the companies listed in the Nairobi securities exchange. The study therefore rejects the null hypothesis that there is no significant joint effect of money supply, oil prices, gross domestic product and interest rate on stock returns of the companies listed in the NSE.

\section{References}

Ariemba, J. M., Mboya, K. J., \& Kamau, R. G. (2015). The Influende of Macroeconomics Factors on Mortgage Market Growth in Kenya. Unpublished.

Atanda, O. (2012). Causal Relations among Stock Prices and Macroeconomic Variablesin the Small Open Economy of Jordan. Economics and Administration, 17(2), 3 - 12.

Barno, C. (2014). The Effect of Macroeconomic Variables on Stock Market Returns in Ghana. Walden University. Unpublished.

Basher, S. A., Haug, A. A., \& Sadorsky, P. (2011). Oil Prices, Exchange rates and Emerging Stock Markets. Unpublished.

Basu, K. (2011). Understanding Inflation and Controlling it. Economics and Political Weekly, 46(41), 50 - 64.

Brealey, R. A., \& Myers, C. F. (2011). Principles of Corporate Finance. Unpublished.

Cooper, R. D., \& Schindler, S. P. (2014). Business Research Methods. Twelve Edition.

Erdugan, R. (2012). The Effect of Economic Factors on Performance of the Australian Stock Market. Victoria University. Unpublished.

Evusa, Z., Kitati, E. M., \& Maithya, H. S. (2015). Effect of Macroeconomic Variables on Stock Market Prices for the Companies Quoted on the Nairobi Securities Exchange in Kenya. Sciences: Basic and Applied Research, 21(2), $235-263$.

Gatebi, M. (2013). Macroeconomic Variables and Volatility of Common 40 Stock Returns in Kenya. Jomo Kenyatta University of Agriculture and Technology. Nairobi: Unpublished.

Junkin, K. (2012). Macroeconomic Determinants on Stock Market Behaviour in South Africa. Rhodes University. Unpublished.

Kalui,F.M. (2004). Determinants of Stock Price Volatility; An Empirical Investigation of Nairobi Stock Exchange. University of Nairobi,Unpublished.

Kamande, M. N. (2017). Macroeconomic Variables and Stock Market Return in Nairobi Securities Exchange. Kenyatta University, Nairobi.

Kirui, E., Wawire, N. H., \& Onono, P. O. (2014). Macroeconomic Variables, Volatility and Stock Market Returns. Economic and Finance, 6(8), 214 - 228.

Kuwornu, M. K., \& Nantwi, O. V. (2011). Macroeconomic Variables and Stock Market Returns :Full Information 
Maximum Likelihood Estimation. Finance and Accounting, 2(4), 49 - 63.

Mugambi, M., \& Okech, T. C. (2016). Effect of macroeconomic variables on stock returns of listed commercial banks in Kenya. Economics, Commerce and management, 4(6), 390 - 418.

Mwaore, M. W. (2017). The Effect of Macroeconomic Variables on Share Prices of Firms Listed in Nairobi Securities Exchange. University of Nairobi. Nairobi: Unpublished.

Ndegwa, E. N. (2015). Effect of Macro Economic Variables on Stock Market Return at the Nairobi Securities Exchange. University of Nairobi, Nairobi.

Nse. (ww.nse.coke/media-center/press-release.html). Retrieved August 17, 2016, from website https.

Olukayode, E. M., \& Akinwande, A. A. (2009). Does Macroeconomic Indicators Exert Shock on the Nigerian Capital Market? Unpublished.

Olweny, T., \& Omondi, K. (2011). The Effect of Macro - Economic Factors On Stock Return Volatility in the Nairobi Securities Exchange, Kenya. Economics and Finance, 1(10), 34 - 48.

Ouma, W. N., \& Muriu, P. (2014). Impact of Macroeconomic Variables on Stock Market Returns in Kenya. Business and Commerce, 3(11), 1 - 31.

Schiller, B. R. (2008). The Macro Economy Today. Eleventh Edition. Chicago: Adventure Works Press.

Sifunjo, E., \& Mwasaru, A. (2012). The Causal Relationship Between Stock Prices and Exchange Rates in Kenya. Finance and Accounting, 3(7), 121 - 130.

Songole, R. K. (2012). The Relationship Between Selected Macroeconomic Variables and Stock Returns at the Nairobi Securities Exchange. University of Nairobi. Nairobi: Unpublished.

Wang, L. (2010). Empirical Analysis of Macroeconomic Factors Affecting Stock Prices. Orient Academic Forum. $132-133$

Zhang, G. (2009). Informational Efficiency of Credit Default Swap and Stock Market: The Impact of Adverse Credit Events. Accounting, Banking and Finance, 1(1), 1 - 15. 